\title{
A comprehensive review of peptide toxins vs synthetic modulators of BK channels in Epilepsy
}

\author{
E. Susithra1, Gouthami Thumma ${ }^{2}$, Naveena Lavanya Latha Jeevigunta ${ }^{3 \mathrm{a}}$, MV. Basaveswara Rao ${ }^{3 \mathrm{~b} *}$, Kiran Gangarapu ${ }^{4 *}$ \\ ${ }^{1}$ Department of Pharmacognosy, School of Sciences, Vels institute of Science, Technology and Advanced Studies (VISTAS), Pallavaram, Chennai- \\ 60017, Tamilnadu, India \\ ${ }^{2}$ Department of Pharmaceutics, University College of Pharmaceutical Sciences, Kakatiya University, Warangal-506003, Telangana, India \\ ${ }^{3 a}$ Department of Biotechnology, Krishna University, Machilipatnam - 521001, Krishna district, Andhra Pradesh, India \\ ${ }^{3 b}$ Department of Chemistry, Krishna University, Machilipatnam - 521001, Krishna district, Andhra Pradesh, India \\ ${ }^{4}$ School of Pharmacy, Anurag Group of Institutions, Hyderabad-500 088, Telangana, India
}

Corresponding Author: Naveena Lavanya Latha Jeevigunta, Department of Biotechnology, Krishna University, Machilipatnam - 521001, Krishna district, Andhra Pradesh, India

Received date: June 02, 2021; Accepted date: June 07, 2021; Published date: June 17, 2021

Citation: Susithra E., Thumma G., Naveena L. L.Jeevigunta, MV. Basaveswara Rao, Gangarapu K. (2021) A comprehensive review of peptide toxins vs synthetic modulators of BK channels in Epilepsy. J. Obstetrics Gynecology and Reproductive Sciences. 5(5): DOI: 10.31579/2578-8965/082

Copyright: MV. Basaveswara Rao @ 2021 , This is an open access article distributed under the Creative Commons Attribution License, which permits unrestricted use, distribution, and reproduction in any medium, provided the original work is properly cited.

\begin{abstract}
:
BK channels, or voltage-gated $\mathrm{Ca} 2+$ channels, are essential regulators of neuronal excitability and muscular contractions, all of which are abnormal in epilepsy, a chronic neuronal disease. The form, frequency, and transmission of action potentials (APs), as well as neurotransmitter release from presynaptic terminals, are all influenced by BK channels found in the plasma membrane of neurons. Over the last two decades, several naturally occurring BK channel modulators have attracted a lot of attention. The structural and pharmacological properties of BK channel blockers are discussed in this article. The properties of various venom peptide toxins from scorpions and snakes are first identified, with a focus on their distinctive structural motifs, such as their disulfide bond formation pattern, the binding interface between the toxin and the BK channel, and the functional consequences of the toxins' blockage of BK channels. Then, several non-peptide BK channel blockers are discussed, along with their molecular formula and pharmacological impact on BK channels. The precise categorization and explanations of these BK channel blockers are hoped to provide mechanistic insights into BK channel blockade. The structures of peptide toxins and non-peptide compounds may serve as models for the development of new channel blockers, as well as aid in the optimization of lead compounds for use in neurological disorders.
\end{abstract}

Keywords: BK channels, peptide toxins, chemical mimetics, synthetic modulators, epilepsy

\section{Introduction:}

Epilepsy is a chronic disorder in which neuronal hyperexcitability and excessive synchronization generate abnormal brain electrical activity (seizures), which can in turn produce absences, loss of consciousness, limb stiffening and/or jerking (convulsions), or atonia.

Channelopathy disorders are caused by the abnormal functioning of ion channel subunits [4]. The leading sources of channel dysfunction are de novo and inherited nucleotide changes, which can be classified as gainor loss-of-function (GOF, LOF) mutations. GOF mutations alter channel activity in a way that increases current magnitude or duration, whereas LOF produces the opposite effect, to reduce current size or duration. BK channels are large-conductance, voltage, and calcium-activated potassium channels. BK channels leads to massive efflux of $\mathrm{K}+$ ions, that hyperpolarizes cellular membrane potential [17]. They conduct large amount of $\mathrm{K}$ ions across the cell membrane hence their name big potassium [9]. These channels are activated opened by either electrical means or by increasing calcium concentration in cell [10]. BK channels help regulate physiological processes such as neuronal excitability, smooth muscle contractility and circadian behavioral rhythms [18]. It is also involved in many processes in the body as it is a ubiquitous channel. It has not yet been established how the genetic changes alter BK channel function and under which conditions these alterations manifest [9] Depolarization of the membranevoltage and increased intracellular $\mathrm{Ca} 2+$ levels both cause BK channels to open, whichhyperpolarizes the membrane and closes voltage-dependent channels, including $\mathrm{Ca} 2+$ channels, reducing $\mathrm{Ca} 2+$ influx into the cell [6]. Gating by voltage and $\mathrm{Ca} 2+$ confers specialized regulation of membrane potential in 
excitable cells. BK channels are expressed widely in neurons and muscle, where they exert specific effects on membrane potential through different splice variants, interactions with accessory subunits, and coupling to $\mathrm{Ca} 2+$ sources [17]This selective tuning of BK channel properties through different molecular mechanisms and protein interactions produces distinct functional consequences for excitability. In the brain, the BK channel performs dual roles in regulating excitability depending on neuronal type [9] For example, BK channel activation can either deaccelerate (Purkinje neurons) or speed (GABAergic neurons) action potential (AP) firing, and therefore modulate neurotransmitter release Latorre et al. 2017; Tseng-Crank et al. 1994). Thus BK channels manifest their pivotal role in preventing transmitter-related hyperexcitability, and therefore neuronal dysfunction, through this balance of activity.

They have tetrameric structure that is composed of a transmembrane domain voltage sensing, potassium channel and a cytoplasmic c-terminal domain.[15] Their function is repolarizing the membrane potential by allowing for potassium to flow outward response in response to depolarization or increase in $\mathrm{Ca}+2$ levels (Castillo, Contreras et al. 2015). Structure:

BK channels are homologous to voltage and ligand gated $\mathrm{K}+$ channelhaving a voltage sensor and pore as the membrane spanning domain in a cytosolic domain for the binding of intracellular $\mathrm{Ca}$ and $\mathrm{Mg}$ each monomer of the channel forming alpha subunit is the product is consisting of Kca1 gene also known as slo1.(Horrigan, Gonzalez et al. 2019) It has three main structural domain such as 1) the voltage sensing domain (VSD) senses membrane potential across the membrane, 2) the cytosolic domain (senses calcium concentration, $\mathrm{Ca}^{2+}$ ions), and 3) the pore-gate domain (PGD) which opens and closes to regulate potassium permeation. [12]

BK channels are large conductance of $\mathrm{Ca}$ gated and $\mathrm{K}+$ channels and it consists of $4 \square$ subunits and one gene encoded for this is KCal gene [4]. They are six transmembrane domain $\mathrm{K}+$ channel has two main subunits such as: 1) Voltage gated $\mathrm{K}+$ channels $(\mathrm{Kv})$. 2) Calcium gated $\mathrm{K}+$ channel (Kca).(Cheng, Wright et al. 2016)

The $\mathrm{Kv}$ has subclassified into $\mathrm{Kv} 1$ to $\mathrm{Kv} 12$ and $\mathrm{Kv} 1$ is subclass into Kv1.1 to Kv1.8 and are formed from the total 40 genes.(Stevens and Patel 2016)They also have intrinsic calcium binding sites in their carboxyl terminal tail that impart low affinity calcium activation. They have a potassium selectivity sequence that allows high conductance while maintaining selectivity for potassium. BK channels also assemble with a family of twotransmembrane accessory $\square$ subunits ( $\square 1-\square 4$ ), through interactions in the N-terminus-S3 domain.[16]

From the functional point of view, all $\mathrm{Kv}$ channels are activated by depolarization and deactivated by repolarization, both relatively fast. Inactivation occurs when the open channel is occluded via intracellular "ball domains" during prolonged depolarization.

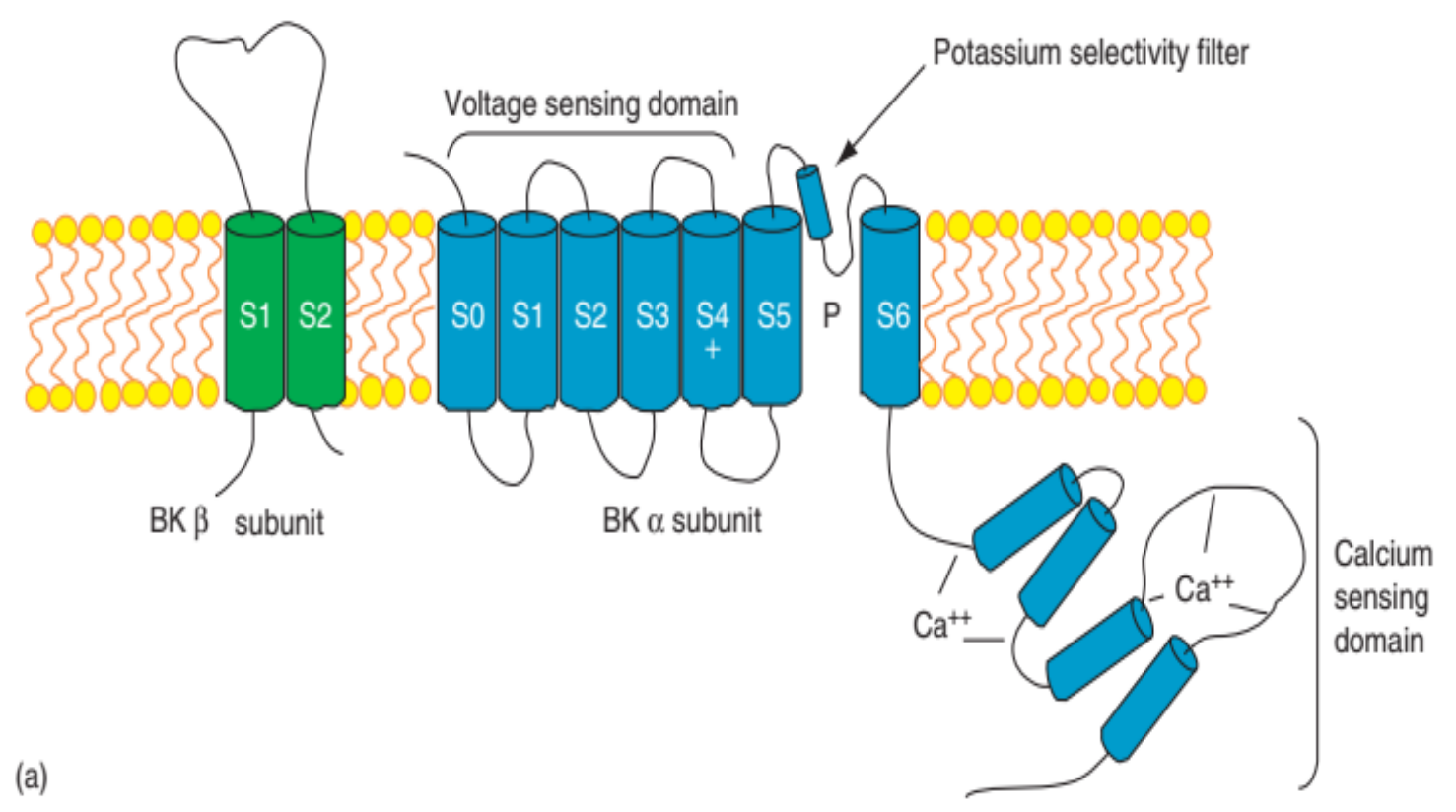

Voltage activation

Calcium activation

Voltage and calcium 


\section{Location:}

In the central nervous system (CNS), BK channels located in the plasma membrane of neurons influence the shape, frequency, and propagation of action potentials (APs), as well as neurotransmitter release from presynaptic terminals.(Zhang, Gadotti et al. 2018) BK channels located in the nuclear envelope of neurons can also directly influence gene transcription and neuronal morphology. Kca channels are mostly located at the dendrites and axon terminals. [16]. Furthermore, BK channels expressed in non-neuronal cell populations, such as astrocytes or vascular smooth muscle cells, can regulate cerebral blood flow, thereby influencing brain activity.

\section{Naturally-Occurring BK Channel Modulators}

Many naturally occurring BK channel modulators has received considerable interest over a last two decades. Here we report the recently developed BK channel inhibitors from the natural origin, many BK channel inhibitors are peptide toxins among which are isolated from scorpions. Venom from scorpions has proved to be an invaluable source of peptide toxins with BK channel blocker properties. The 37-amino acid peptide charybdotoxin (ChTX), isolated from the venom of Leiurusquinquestriatus is a potent BK blocker[15].

\begin{tabular}{|c|c|c|c|c|c|}
\hline S.No & Toxin & Length & Scorpion Sources & PDB ID's & $\mathrm{IC}_{50}(\mathrm{nmol} / \mathrm{L})$ \\
\hline 01 & $\begin{array}{l}\text { Charybdotoxin } \\
\text { (ChTX) }\end{array}$ & 37 aa & $\begin{array}{c}\text { Leiurisquinquestriatus } \\
\text { and } \\
\text { Leiurusquinquestriatushebraeus }\end{array}$ & $\begin{array}{c}\text { 1BAH, 1CMR, } \\
\text { 2A9H, 2CRD, } \\
\text { 4JTA, 4JTC, 4JTD, } \\
\text { 1L1R } \\
\end{array}$ & $50 \& 43$ \\
\hline 02 & Iberiotoxin & $37 \mathrm{aa}$ & Buthustamulus & -- & $2-10$ \\
\hline 03 & Limbatustoxin & $37 \mathrm{aa}$ & Centruidslimbatus & & \\
\hline 04 & BmTx1; BmTx2 & $37 \mathrm{aa}$ & ButhusmartensiKarsch(Chinese) & $\begin{array}{r}1 \mathrm{BIG} \\
2 \mathrm{BMT}\end{array}$ & $0.6 \& 0.3$ \\
\hline 05 & $\begin{array}{l}\text { Lqh 15-1 } \\
\text { (Chtx2) }\end{array}$ & $37 \mathrm{aa}$ & Leiursquinquestriatus(hebreus) & & 50 \\
\hline 06 & Slotoxin & $37 \mathrm{aa}$ & Centruroidesnoxius(Hoffmann) & & 1.5 \\
\hline 07 & $\begin{array}{l}\text { Kaliotoxin } \\
\text { (KTX) }\end{array}$ & $37 \mathrm{aa}$ & Androctonusmauretanicus & $\begin{array}{c}\text { 3ODV, 1KTX, } \\
\text { 2KTX, 2UVS, } \\
\text { 1XSW } \\
\end{array}$ & 20 \\
\hline 08 & $\begin{array}{c}\text { Kaliotoxin } 2 \\
\text { (KTX2) }\end{array}$ & & Androctonusaustralis & & 135 \\
\hline 09 & $\begin{array}{l}\text { Butantoxin } \\
\text { (BuTX, } \\
\text { TsTX-IV) }\end{array}$ & 40aa & Tityusserrulatus(Brazilian) & $\begin{array}{c}\text { 1C55, 1C56, } \\
1 \mathrm{WT} 7\end{array}$ & $10-50$ \\
\hline 10 & $\begin{array}{c}\text { Martentoxin } \\
\text { (MarTX, } \\
\text { BmTx3B) }\end{array}$ & $37 \mathrm{aa}$ & ButhusmartensiKarsch(Chinese) & $1 \mathrm{M} 2 \mathrm{~S}$ & 78 \\
\hline 11 & $\begin{array}{c}\text { BmBKTx1 } \\
\text { (BmK37) }\end{array}$ & $31 \mathrm{aa}$ & ButhusmartensiKarsch(Asian) & $1 \mathrm{Q} 2 \mathrm{~K}$ & 82 \\
\hline 12 & BmP09 & 66aa & ButhusmartensiKarsch(Chinese) & & 27 \\
\hline 13 & natrin & 221aa & snake Najiaatra & $1 \mathrm{XX5}$ & 34.4 \\
\hline
\end{tabular}

Table 1: Peptide toxins from scorpions as BK channel inhibitors

Iberiotoxin (IBTX), a 37-amino acid peptide isolated from the venom of the scorpion Buthustamulus is, instead, a selective and high affinity blocker of BK channels, providing a first-choice blocker for studying the functions and structure of the BK channels (Yu, Liu et al. 2016). 
<smiles>COc1ccc(-c2cc(=O)c3c(OC)c(OC)c(OC)c(OC)c3o2)cc1OC</smiles>

Nobiletin (1)

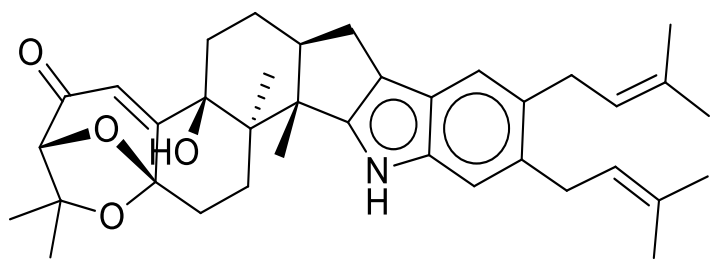

Shearinine K (3)<smiles>COc1ccc(CC2C=CC3=CC=C(CC4c5cc(c(OC)cc5CCN4C)Oc4c(OC)c(OC)cc(CCN)c42)c2ccc(CC4c5cc(OC)c(OC)cc5CCN4C)cc2O3)cc1</smiles>

Tetrandrine (5)<smiles>CC(C)(O)C1OC2CCC3(C)C(CCC4Cc5c([nH]c6ccccc56)C43C)C2=CC1=O</smiles>

\section{Paxilline (2)}<smiles>CC=C1C2CCC3(O)C4=CC(=O)C5OC14CCC3(C)C5(C)Oc1[nH]c3cc4c(cc3c1C2)CC1C4=CC(C)(C)OC1(C)C</smiles>

Shearinine A (4)<smiles>CC12CCC3c4ccc(O)cc4CCC3C1CCC2O</smiles>

17 -Estradiol (6)

\section{Figure 2:Natural BK-channel inhibitors}

Sun et al., has reported Nobiletin which is a Hexamethoxyflavone (1), found in citrus peels which is used in Chinese traditional medicine has property of inhibiting BK channel. Nobiletin has shown various beneficial effects such as neurotropic, decreases dementia, modulates biogenic amines. The results of patch clamp studies nobiletin inhibit BK channels in both $\mathrm{Ca}$ and voltage dependent manner. In $100 \mu \mathrm{M} \mathrm{Ca}{ }^{2+}$, nobiletin reduces channel activity at all voltages tested, with an $\mathrm{IC}_{50}$ of $10.4 \mu \mathrm{M}$ at $-80 \mathrm{mV}$. It is less effective on channels composed of Slo1 and $\beta 2$ subunits. (Sun, Gonzalez et al. 2019)

17 $\square$-Estradiol (6) modulates the BK channels has reported by Sara et al., and they proposed the binding sites of BK channel and they demonstrated that the presence of $\square 1$ subunit is essential for this modulatory effect.
They have concluded the W163residue is directly involved in the binding between the17 $\square$-Estradiol and BK channel.(Granados, Bravo et al. 2016)

\section{Synthetic BK Channel Inhibitors}

Notwithstanding the poor selectivity among potassium channels, tetraethyl ammonium chloride (TEA, 6) is the most widely used small molecule and synthetically-derived BK channel blocker, which evidently emphasizes the lack of selective BK blockers with this origin. Ancillary BK channel inhibition has been shown to be an effect of diagnostic agents, such as nitroblue tetrazolium, a number of marketed drugs, including verapamil and analogues, as well as investigational drugs originallydesigned for different biological targets, such as ketamine, clotrimazole 


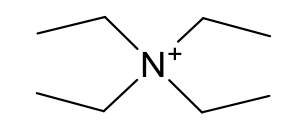

Tetraethylammonium (6)<smiles>COc1ccc(CCN(C)CCCC(C#N)(c2ccc(OC)c(OC)c2)C(C)C)cc1OC</smiles>

Verapamil (7)<smiles>CNC1(c2ccccc2Cl)CCCCC1=O</smiles>

Ketamine (8)<smiles>CC(=O)OOC(=O)O[Na]</smiles><smiles>CCC(C)(C)C(=O)OC1CC(C)C=C2C=CC(C)C(CCC3CC(O)CC(=O)O3)C21</smiles>

Simvastatin (10)

Figure 3: Chemical structures of marketed and/or investigational drugs with BK-inhibiting properties

Zileuton a 5-lipoxygenase inhibitor exerts anti-proliferative and anti- zileuton supresses VEGF-induced angiogenesis and reversed by IBTX angiogenesis action by modulating the BK channel was reported by

(Natural BK channel blocker) and these experimental data suggests that Hyun-Joung Limet al., by evaluating on BK channel specific siRNA. zileuton exerts anti-angiogenic property by BK channel opening.(Lim, They have demonstrated by using BrdU incorporation assay in which

Park et al. 2019)<smiles>CC(c1cc2ccccc2s1)N(O)C(N)=O</smiles>

Zileuton (11)<smiles>O=c1[nH]c2cc(C(F)(F)F)ccc2n1-c1cc(C(F)(F)F)ccc1O</smiles>

NS1619 (12)<smiles>O=C(/C=C/c1ccc(O)cc1)c1ccc(O)cc1O</smiles>

Isoliquiritigenin (13)<smiles>CC(CO)NC(=O)c1cccc(C=CCCCC(=O)N(C)C)c1</smiles>

3-(6-(dimethylamino)-6-oxohex-1-en-1-yl)-N-(1-hydroxypropan-2-yl) benzamide (14) 


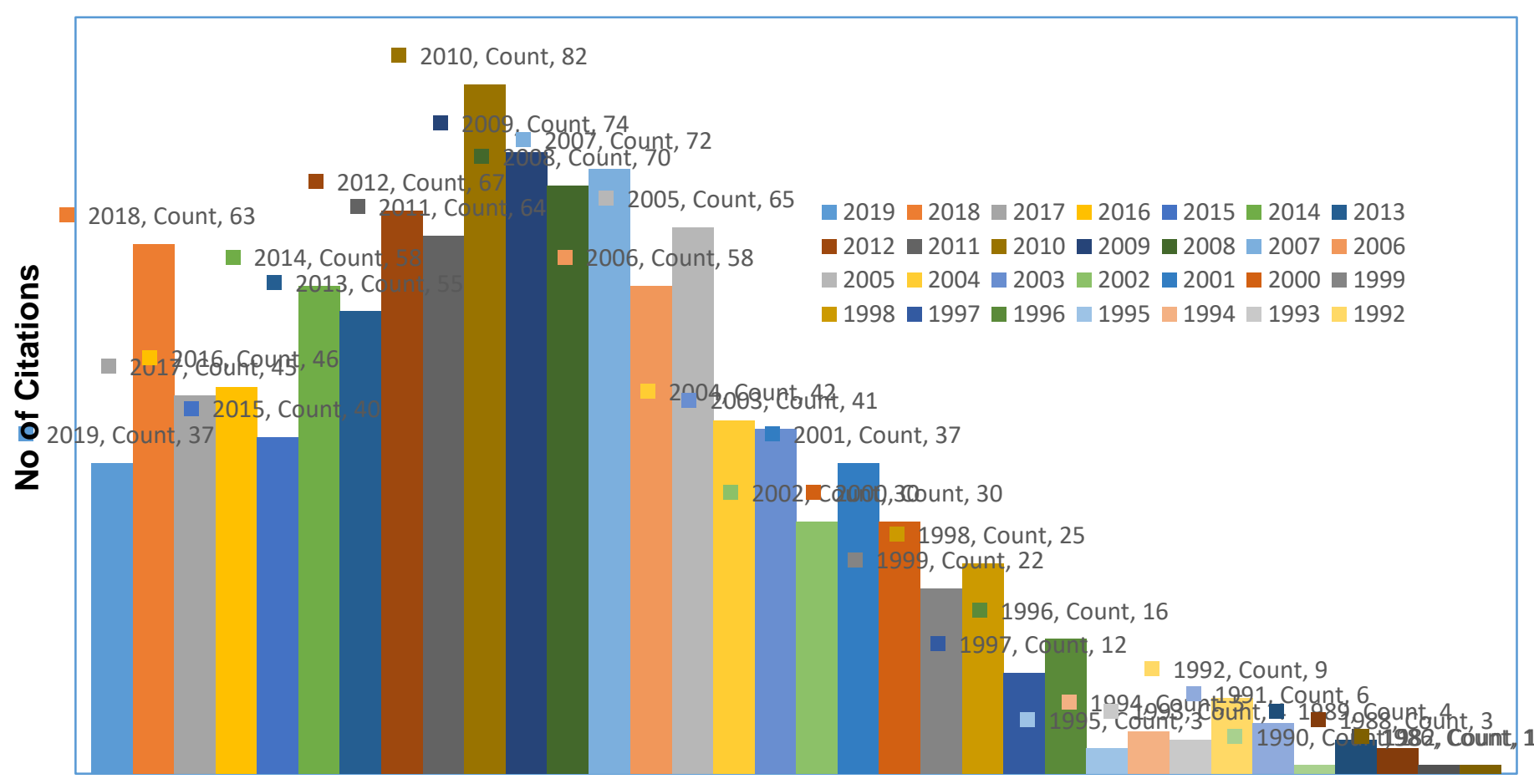

Year

Figure 4: No of Citations per year in Pubmed for BK channels from 2008 to 2019

\begin{tabular}{|c|c|}
\hline BK channel Opener & BK channel Blocker \\
\hline Zileuton & Iberiotoxin \\
NS1619 & \\
17ß-estradiol & \\
Isoliquiritigenin & \\
3-(6-(dimethylamino)-6-oxohex-1-en-1-yl)-N-(1- & \\
hydroxypropan-2-yl) benzamide(VSN16R) & \\
(5-[(4-bromophenyl)methyl]-1,3-thiazol-2-amine) & \\
(NS19504) & \\
\hline
\end{tabular}

\section{Crystal structures of BK channel}

\begin{tabular}{|c|c|c|c|c|c|c|c|c|}
\hline S.No & $\begin{array}{c}\text { Crystal } \\
\text { structure }\end{array}$ & Resolution & Chains & $\begin{array}{c}\text { Gene } \\
\text { Name }\end{array}$ & $\begin{array}{l}\text { Sequence } \\
\text { Length }\end{array}$ & Source & Ligand & Ref \\
\hline 01 & $3 \mathrm{U} 6 \mathrm{~N}$ & $3.61 \AA$ & $\begin{array}{c}8 \text { chains; } \\
\text { A,B,C,D,E,F,G,H }\end{array}$ & KCNMA1 & 696 & Danio rerio & $\mathrm{Ca}$ & $\begin{array}{l}\text { http://dx.doi.org/10. } \\
\text { 2210/pdb3U6N/pdb }\end{array}$ \\
\hline 02 & 3MT5 & $3 \AA$ & $\mathrm{A}$ & KCNMA1 & 726 & Homo sapiens & Sulfate and $\mathrm{Ca}$ & $\begin{array}{l}\text { http://dx.doi.org/10. } \\
\text { 2210/pdb3MT5/pdb }\end{array}$ \\
\hline 03 & $3 \mathrm{NAF}$ & $3.10 \AA$ & A & KCNMA1 & 798 & Homo sapiens & $\begin{array}{c}(2 \mathrm{~S})-2- \\
\text { aminobutanoic } \\
\text { acid }\end{array}$ & $\begin{array}{l}\text { http://dx.doi.org/10. } \\
\text { 2210/pdb3NAF/pdb }\end{array}$ \\
\hline 04 & 1ID1 & $2.4 \AA$ & $\mathrm{A}, \mathrm{B}$ & kch & 153 & $\begin{array}{c}\text { Escherichia } \\
\text { coli (strain } \\
\text { K12) }\end{array}$ & & $\begin{array}{l}\text { http://dx.doi.org/10. } \\
\text { 2210/pdb1ID1/pdb }\end{array}$ \\
\hline
\end{tabular}




\section{References:}

1. Castillo, K., G. F. Contreras, A. Pupo, Y. P. Torres, A. Neely, C. González and R. Latorre (2015). "Molecular mechanism underlying $\beta 1$ regulation in voltage-and calcium-activated potassium (BK) channels." Proceedings of the National Academy of Sciences112(15): 4809-4814.

2. Cheng, Y. Y., C. M. Wright, M. B. Kirschner, M. Williams, K. H. Sarun, V. Sytnyk, I. Leshchynska, J. J. Edelman, M. P. Vallely and B. C. McCaughan (2016). "KCa1. 1, a calcium-activated potassium channel subunit alpha 1 , is targeted by miR-17-5p and modulates cell migration in malignant pleural mesothelioma." Molecular cancer15(1): 44.

3. Cobb, M. M. (2015). Regulation of Kv2. 1 Channel Complexes, University of California, Davis.

4. Gonzalez-Perez, V. and C. J. Lingle (2019). "Regulation of BK channels by beta and gamma subunits." Annual review of physiology81: 113-137.

5. Granados, S. T., F. Bravo, R. Sepúlveda, D. González-Nilo, J. Gonzalez, R. Latorre and Y. Torres (2016). "17 $\beta$-Estradiol Binds and Modulates BK Channel through its $\beta 1$ Auxiliary Subunit." Biophysical Journal110(3): 280a-281a.

6. Honrath, B., I. E. Krabbendam, C. Culmsee and A. M. Dolga (2017). "Small conductance Ca2+-activated $\mathrm{K}+$ channels in the plasma membrane, mitochondria and the ER: Pharmacology and implications in neuronal diseases." Neurochemistry international109: 13-23.

7. Horrigan, F. T., L. A. Gonzalez, L. Sun, M. Bloch and S. Zou (2019). "A Novel High-Throughput Screening Assay for StateDependent and Subunit-Dependent BK Channel Modulators." Biophysical Journal116(3): 248a.

8. Hoshi, T. and S. Heinemann (2016). Modulation of BK channels by small endogenous molecules and pharmaceutical channel openers. International review of neurobiology, Elsevier. 128: 193237.
9. Kaczorowski, G. and M. Garcia (2016). Developing molecular pharmacology of BK channels for therapeutic benefit. International review of neurobiology, Elsevier. 128: 439-475.

10. Leo, A., R. Citraro, A. Constanti, G. De Sarro and E. Russo (2015). "Are big potassium-type Ca2+-activated potassium channels a viable target for the treatment of epilepsy?" Expert opinion on therapeutic targets 19(7): 911-926.

11. Lim, H.-J., J. Park, J.-Y. Um, S.-S. Lee and H.-J. Kwak (2019). "Zileuton, a 5-Lipoxygenase Inhibitor, Exerts Anti-Angiogenic Effect by Inducing Apoptosis of HUVEC via BK Channel Activation." Cells8(10): 1182.

12. Miranda, P., T. Giraldez and M. Holmgren (2015). "Voltage dependence of BK channels gating ring motion studied by state dependent FRET." Biophysical Journal108(2): 119a.

13. Stevens, E. and M. Patel (2016). "BS Barker1, GT Young2, CH Soubrane2, GJ Stephens3." Conn's Translational Neuroscience: 11.

14. Sun, L., L. A. Gonzalez and F. T. Horrigan (2019). "Nobiletin Inhibition of BK Channels." Biophysical Journal1 16(3): 104a.

15. Yu, M., S.-1. Liu, P.-b. Sun, H. Pan, C.-l. Tian and L.-h. Zhang (2016). "Peptide toxins and small-molecule blockers of BK channels." Acta Pharmacologica Sinica37(1): 56.

16. Zang, K., Y. Zhang, J. Hu and Y. Wang (2018). "The Large Conductance Calcium-and Voltage-activated Potassium Channel (BK) and Epilepsy." CNS \& Neurological Disorders-Drug Targets (Formerly Current Drug Targets-CNS \& Neurological Disorders)17(4): 248-254.

17. Zhang, F.-X., V. M. Gadotti, I. A. Souza, L. Chen and G. W. Zamponi (2018). "BK potassium channels suppress Cav $\alpha 2 \delta$ subunit function to reduce inflammatory and neuropathic pain." Cell reports22(8): 1956-1964.

18. Zhang, G., Y. Geng, J. Shi, K. McFarland, K. L. Magleby, L. Salkoff and J. Cui (2016). "Deletion of Cytoplasmic Gating Ring Alters Voltage Dependent Activation of BK Channels." Biophysical Journal110(3): 186a-187a.

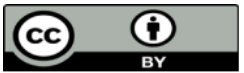

This work is licensed under Creative Commons Attribution 4.0 License

To Submit Your Article Click Here: Submit Manuscript

DOI: $10.31579 / 2578-8965 / 082$
Ready to submit your research? Choose Auctores and benefit from:

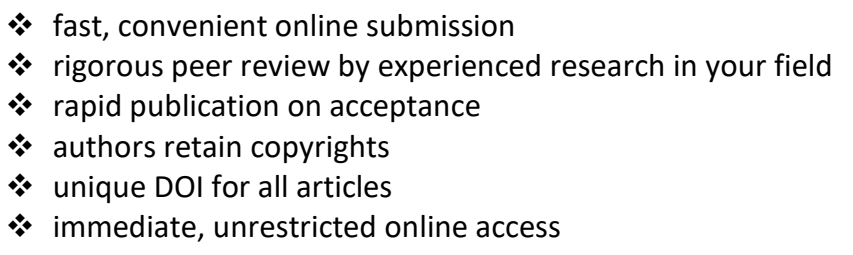

At Auctores, research is always in progress.

Learn more www.auctoresonline.org/journals/obstetrics-gynecology-andreproductive-sciences 